\title{
Felületes vénás thrombosis - ahogy ma látjuk
}

\author{
Sándor Tamás dr.
}

\author{
Semmelweis Egyetem, Általános Orvostudományi Kar, II. Sebészeti Klinika, Budapest
}

\begin{abstract}
A felületes thrombophlebitist hosszú időn át meglehetôsen jóindulatú betegségnek tartották. Újabban, amióta a diagnózishoz egyre gyakrabban használnak duplex ultrahangtechnikát, kiderült, hogy a betegség veszélyesebb, mint ahogy azt eddig gondoltuk. A thrombosis az esetek 6-44\%-ában a mélyvénákra terjed, tüdőembóliát pedig a betegek 1,5-33\%-ánál észleltek. Minden negyedik betegnél alakul ki vénás thromboemboliás szövődmény. A diagnózis klinikai, de a duplex ultrahangvizsgálatot mindig el kell végezni a thrombus kiterjedésének meghatározására, a mélyvénás thrombosis kizárására. Ezzel a vizsgálattal ellenőrizzük később is a betegeket. Ultrahanggal mindkét lábat meg kell vizsgálni, mert egyidejü mélyvénás thrombosis az ellenoldali végtagon is kialakulhat. A betegség két formáját lehet megkülönböztetni: felületes vénás thrombosis varicosus vénákon vagy varicositas nélkül. A spontán, nem varicosus formában, különösen, ha a folyamat migráló vagy kiújuló, a betegek gondos kivizsgálásra szorulnak, azért, hogy a malignus betegségeket és a thrombophiliát kizárjuk. A kezelési lehetőségeket a legújabb nemzetközi konszenzus alapján foglaljuk össze. Az amerikai és a német útmutatók hasonlóak. A kompresszió és a mobilizáció a terápia sarkköve. Rövid szegmentű thrombosisnál a nem szteroid gyulladáscsökkentő gyógyszerek hatásosak. Hosszabb szegmentnél előnyösebbek a kis molekulasúlyú heparinok. Az új, orális antikoagulánsokkal végzett kezelésre vonatkozó információval nem rendelkezünk. A jövő́ben ezek a gyógyszerek ebben az indikációban is hatásosak lehetnek. Ha a thrombus a saphenofemoralis vagy saphenopoplitealis junctióhoz közel van, crossectomiát (magas lekötést) kell végezni vagy terápiás dózisban kis molekulasúlyú heparint kell adni. Ne használjuk a felületes thrombophlebitis kifejezést, mert nem a gyulladás és fertőzés a patológia primer tényezője. Felületes vénás thrombosis az új, helyes elnevezés, azért, hogy ne adjunk feleslegesen antibiotikumokat, és elkerüljük azt a téves feltételezést, hogy a felületes vénás thrombosis benignus betegség. Orv. Hetil., 2017, 158(4), 129-138.
\end{abstract}

Kulcsszavak: ultrahang, kompresszió, mobilizáció, gyógyszerek, crossectomia

\section{Superficial venous thrombosis. A state of art}

For a long time superficial thrombophlebitis has been thought to be a rather benign condition. Recently, when duplex ultrasound technique is used for the diagnosis more and more often, the disease is proved to be more dangerous than anticipated. Thrombosis propagates to the deep veins in 6-44\% and pulmonary embolism was observed on the patients in $1,5-33 \%$. We can calculate venous thromboembolic complications on every fourth patient. Diagnosis is clinical, but duplex ultrasound examination is mandatory, for estimation of the thrombus extent, for exclusion of the deep venous thrombosis and for follow up. Both legs should be checked with ultrasound, because simultaneous deep venous thrombosis can develop on the contralateral limb. Two different forms can be distinguished: superficial venous thrombosis with, or without varicose veins. In cases of spontaneous, non varicous form, especially when the process is migrating or recurrent, a careful clinical examination is necessery for exclusion of malignant diseases and thrombophilia. The treatment options are summarised on the basis of recent international consensus statements. The American and German guidelines are similar. Compression and mobilisation are cornerstones of the therapy. For a short segment thrombosis non steroidal antiinflammatory drugs are effective. For longer segments low molecularweight heparins are preferred. Information on the effect of the novel oral anticoagulants for the therapy is lacking but they may appear to be effective in the future for this indication. When thrombus is close to the sapheno-femoral or sapheno-popliteal junction crossectomy (high ligation), or low molecular-weight heparin in therapeutic doses are indicated. The term superficial thrombophlebitis should be discouraged, because inflammation and infection is not the primary pathology. It should be called correctly superficial venous thrombosis in order to avoid the unnecessary administration of antibiotics and the misconception, that superficial venous thrombosis is benign disease.

Keywords: ultrasound, compression, mobilisation, drugs, crossectomy

Sándor, T. [Superficial venous thrombosis. A state of art]. Orv. Hetil., 2017, 158(4), 129-138.

(Beérkezett: 2016. szeptember 17.; elfogadva: 2016. november 22.) 


\section{Rövidítések}

LMWH = kis molekulasúlyú heparin; MVT = mélyvénás thrombosis; NSAID $=$ nem szteroid antiinflammatorikus gyógyszer; $\mathrm{PE}=$ pulmonalis embolia; $\mathrm{SVT}$ = superficialis vénás thrombosis; $\mathrm{UFH}=$ nem frakcionált heparin; $\mathrm{UH}=$ ultrahang; $\mathrm{VKA}=\mathrm{K}$-vitamin-antagonista; VTE = vénás thromboembolia

A felületes vénák gyulladással kísért thrombosisa, régi nevén thrombophlebitise, elsősorban az alsó végtagon alakul ki. A mindennapi gyakorlatban gyakran találkozunk vele, a szakkönyvek mégis jóindulatú, jelentéktelen betegségnek tartják, alig írnak róla. Gyakoriságáról nincsenek megbízható adatok. Újabb vizsgálatok szerint az átlagnépességben 3-11\%-ban fordul elő. Nőkön gyakrabban látjuk, fóleg 60 év felett, elsősorban a vena saphena magnán $(60-80 \%)$, ritkábban a vena saphena parván [1]. Egyformán kialakulhat minden évszakban [2]. A betegek is ritkán fordulnak orvoshoz, mert az elváltozás nemegyszer spontán meggyógyul, nincs szükség speciális kezelésre.

Amióta azonban világszerte egyre több thrombophlebitises beteget vizsgálnak duplex ultrahangvizsgálattal, ez a szemlélet alapvetően megváltozott. Összehasonlítva előző tanulmányaimmal $[3,4]$, a betegség megitélésében paradigmaváltás történt. Napjainkban a superficialis thrombophlebitist kevésbé benignus kórképnek tartják. Erre utal a betegség új elnevezése.

\section{Új elnevezés}

A nómenklatúra eddig a felületes folyamatnál a gyulladás, a mélyvénás folyamatnál a thrombosis jelentőségét hangsúlyozta. Innen a „felületes thrombophlebitis” és "mélyvénás thrombosis (phlebothrombosis)" elnevezés.

A legújabb útmutatók nemzetközi konszenzus alapján a betegség új elnevezését javasolják. Ez a ,felületes vénás thrombosis" vagy "felületes vénathrombosis" (superficial venous thrombosis, superficial vein thrombosis) (SVT).

$\mathrm{Az}$ új nómenklatúra szerint tehát felületes vénás thrombosist és mélyvénás thrombosist különböztetünk meg. A primer patomechanizmus alapja ugyanis nem a gyulladás, nem az infekció. Az új elnevezés arra is utal, hogy nem kell antibiotikus kezelés. Hangsúlyozza azt is, hogy a betegség jelentőségét eddig alábecsültük. Téves az az elképzelés, hogy egyértelmúen benignus kórképről van szó $[5,6]$.

\section{Ultrahangvizsgálatok}

Duplex ultrahangvizsgálatok egyértelmúen igazolják, hogy SVT-hez jóval gyakrabban csatlakozik mélyvénás thrombosis (MVT) és tüdőembólia (PE), mint ahogy ezt eddig gondoltuk (1. ábra).

Nagy anyagon két tanulmány foglalkozott ezzel a kérdéssel.

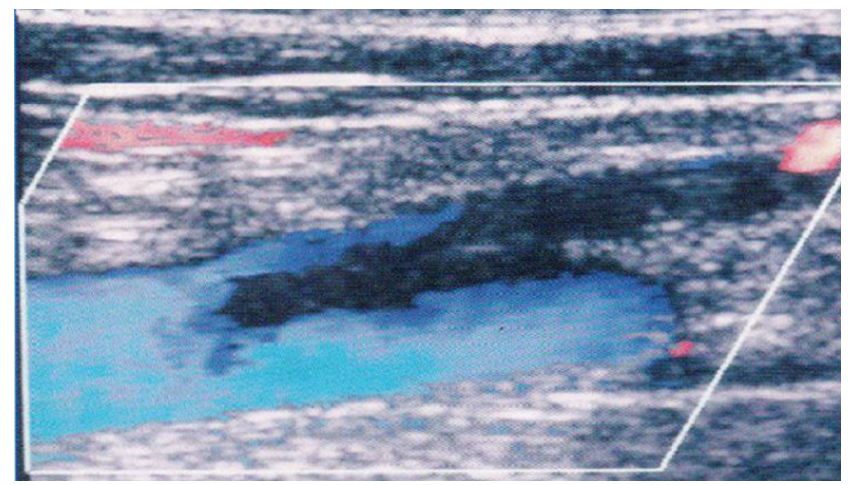

1. ábra

A vena saphena magnában kialakult thrombus ultrahangképe. A thrombus a saphenofemoralis junctión keresztül a vena femoralisba terjed

Franciaországban, a St. Etienne Egyetemi Kórházban 844 konszekutív SVT-s betegen már az első ultrahangvizsgálat során 24,9\%-ban mutattak ki MVT-t vagy PE-t. Három hónappal késóbb a betegek további 10,2\%-án észleltek vénás thromboemboliás (VTE) szövődményt, annak ellenére, hogy 540 beteget antikoagulánsokkal kezeltek [1].

A CALISTO tanulmányban 17 ország 171 centrumában 3002 olyan SVT-s beteget vizsgáltak, akiknél a felületes vénás kötegezettség legalább $5 \mathrm{~cm}$ hosszú volt. A randomizált vizsgálatban a betegeket fondaparinux$\left(\right.$ Arixtra $^{\circledR}$ ) vagy placeboinjekcióval kezelték. Három hónap múlva a fondaparinuxcsoportban 0,9\%-ban (13/1502), a placebocsoportban 5,9\%-ban (88/1500) mutattak ki ultrahangvizsgálattal VTE-t [7].

$\mathrm{Az}$ ultrahangvizsgálatok azt is kimutatták, hogy az SVT nem mindig, ahogy várható, a saphenofemoralis vagy saphenopoplitealis junctiókon át vagy a perforáns vénákon keresztül terjed a mélyvénákra. Az esetek egy részében az SVT-vel egy időben, az ellenkező oldalon, esetleg mindkét lábon vagy a perforáns vénáktól távol eső mélyvénás szakaszon keletkezik MVT [8].

Egy szisztémás, áttekintő tanulmány összegezése szerint az SVT-hez 6-44\%-ban csatlakozik MVT. Ezeken a betegeken $20-33 \%$-ban latens, $2-13 \%$-ban pedig tünetekkel járó PE is kialakul [9]. Az SVT felléptét követően három hónappal a VTE kialakulásának rizikója 3\%, és ez a kockázat még öt év múlva is fennáll [10].

Összefoglalva: Minden negyedik SVT-s betegen számolbatunk VTE-s szövödménnyel.

\section{Patomechanizmus}

A bőr alatt futó véna lumenében thrombus keletkezik. A véna környezetében lévő szöveteken reaktív gyulladásos folyamat kezdődik, ami az ér falát (phlebitis) és a környező szöveteket, nyirokereket, idegeket egyaránt érinti (periphlebitis). A gyakorlatban a folyamat proximalis irányban terjed, csak nagyon ritkán distalisan. Szövettanilag a thrombust keletkezése után fokozatosan gyulladásos sejtek és histiocyták árasztják el, majd a fibroblas- 
tok proliferációja és neoangiogenezis figyelhetô meg. Általában a thrombus az ér falához tapad, ezért, ahogy eddig feltételeztük, a VTE kockázata csekély [3]. Partsch, majd Verlato újabb vizsgálatai azonban kimutatták, hogy a gyulladás nem véd meg a PE kialakulásától. Hasonló arányban, 30\%-ban észleltek PE-t SVT-s betegeken [11, 12].

A fibrosus reakció lehetővé teszi a véna rekanalizációját, ami rendszerint folyamatosan halad elöre, de anatómiai és hemodinamikai károsodást okozhat. A gyulladásos reakció két-három hét, a rekanalizáció rendszerint hat-nyolc hét alatt lezajlik. Előfordulhat azonban, hogy a véna elzáródása végleges, és a folyamat helyén, a bőrön, hiperpigmentált hegszövet marad vissza.

\section{Diagnózis}

A klinikai kép jellegzetes. Az érintett vénás szakasz vörös, meleg, spontán fájdalmas, mint kemény, nyomásérzékeny köteg tapintható. A károsodott vénaszakasz közvetlen környezetében lehet minimális ödéma. Járáskor a gyulladt vénaszakasz alatt fekvő izom megfeszül, ezért a fájdalom fokozódik. A regionális nyirokcsomók - szemben a lymphangitisszel - nem nagyobbak.

A végtagon jelentkező, helyi, körülírt gyulladásos elváltozást általános tünetek kísérhetik: rossz közérzet, hőemelkedés, fokozott süllyedés, leukocytosis, emelkedett CRP.

Felületes vagy mélyvénás thrombosis? Az SVT nem okoz végtagduzzanatot, nem ödémás az egész végtag. MVT-nél látható és mérhetö körfogatkïlönbség jön létre a két végtag között. Nehezíti a kérdés eldöntését, hogy az MVT az esetek kétharmadában latens formában jön létre, erre utaló jelet a végtagon nem találunk.

Nehéz a vena saphena parván kialakult SVT felismerése, mert a véna felső szakasza a fascia alatt fut, ilyenkor a lábikra megduzzadhat, nyomásérzékeny és a Homanstünet (a lábfej dorsalflexiójára bekövetkező lábikrafájdalom) is pozitív lehet, ami MVT gyanúját keltheti.

A diagnózis felállításához általában elég a klinikai megfigyelés. Az esetleges mélyvénás érintettségről azonban csak a duplex ultrahangvizsgálat tájékoztat. Megerősíti az MVT diagnózisát, ha a d-dimer-érték is magas.

A duplex ultrahangvizsgálat SVT-re és MVT-re egyaránt jellegzetes jelei: a véna keresztmetszeti átmérője nagyobb lesz, lumenében homogén, echódús képlet észlelhető, ezért itt a véna nem komprimálható. Néha jellegzetes perivénás háló jelzi a környezeti ödémát [13, 14].

Az SVT-t el kell különiteni a cellulitis, a lymphangitis, az erysipelas, a tendinitis, a neuritis, az izomrostszakadás, a rupturált Baker-cysta, a túltelődő varixok, a fokozott vénás distensio (fogamzásgátló tabletták hatása), a „nyugtalan láb” (éjszakai görcsök), valamint a hypokalaemia eseteitól.

\section{Osztályozás}

A SVT-nek két formája van:

1. A varicosus vénákban fellépő SVT („varicophlebitis”).

2. A nem varicosus vénákon kialakuló SVT („spontán phlebitis").

\section{Varicosus SVT}

A varicositasban szenvedő betegek 10-20\%-án alakul ki, a tágult vénákban a betegség ismert szövődménye. Régi elnevezése: varicophlebitis [15]. Tízszer gyakrabban fordul elö, mint a nem varicosus forma. Fóleg idős betegeken, hosszú állás után figyelhető meg, elsősorban trauma, infekció nyomán [16]. A dilatált vénákban a vér áramlása lelassul. A vénás pangás okozta nagy vénás nyomás hypoxiás endothelkárosodást okoz, leukocytaakkumulációhoz, végső soron koagulációhoz, thrombusképződéshez vezet [17].

Endovénás mútétek természetes velejárója a magas hőmérséklet. A lézerrel, rádiófrekvenciával vagy gőzzel létrehozott nagy meleg elzárja a felületes vénákat. $\mathrm{Az}$ esetek egy részében, bár ritkán, a hatás a mély vénákra is átterjed. Összefoglaló irodalmi adatok szerint 0-7,7\%ban mutattak ki MVT-t endovénás lézerablatio után [18].

\section{Nonvaricosus („spontán”) SVT}

Egyes esetekben a gyulladás, máskor a thrombusképződés a domináló faktor. Ilyenkor a thrombus általában kicsi és a környező szövetek gyulladása is csekély. A megvastagodott intimában myocytainfiltráció és fibroblastproliferáció figyelhető meg, a mediában pedig fibrosis, számos kapillárisképződéssel [16].

A nem varicosus SVT okai szerteágazóak, ezeket az 1. táblázatban tüntettük fel.

1. táblázat |A nem varicosus SVT okai

Szerzett: trauma, mütét, immobilizáció, hosszú repülőút, időskor, terhesség, fogamzásgátló tabletták, posztmenopauzás hormonpótlás.

Infekció: sebfertőzés, rovarcsípés, lábgomba, fogászati gócok, urogenitális fertőzés, orális vagy genitális afták, vírusfertőzés, tbc.

Malignus betegség: főleg pancreas-, tüdő-, gyomor-, prosztatarák.

Szisztémás vasculitis: Bürger-, Beçhet-, Mondor-betegség, polyarteritis nodosa, Horton óriássejtes arteritis, Takayasu-arteritis Collagenosisok: szisztémás lupus erythematosus.

Thrombophilia: Leiden-faktor, protrombingén-mutáció, antitrombin-, protein C-, protein S-hiány, hyperhomocysteinaemia stb.

Hematológiai betegségek: hipokróm anaemia, szekunder polycythaemia, leukaemia, Hodgkin-kór, non-Hodgkin-lymphoma, thrombocytosis stb.

Iatrogén: paravénás injekciók, kemoterápia, drog, radioterápia, tartós kanülök, szkleroterápia. 
A legújabb nemzetközi útmutatók szerint spontán SVT esetén a beteg gondos kivizsgálásra szorul. Elsősorban daganatos betegséget vagy thrombophiliát kell keresni.

A nem varicosus SVT speciális formái:

Thrombophlebitis migrans: A folyamat ép vénás szakaszokat átugorva, proximalis vagy distalis irányba terjed.

Thrombophlebitis saltans: A felületes vénák kisebb-nagyobb szakaszára lokalizált olyan thrombophlebitis, ami váltakozó időközökkel, a test más-más területén, hullámokban jelentkezik. Elsősorban középkorú férfiakon, az alsó végtag külső vagy elülső oldalán alakul ki, néha szimmetrikusan. Ritkán lokalizálódik a lábhátra, felső végtagra, mellkasfalra, esetleg a nyakra. Az egyes hullámok között hetek, hónapok telhetnek el.

A visszatérő, migráló thrombophlebitis mindig valamilyen alapbetegség kiséró jelensége. Ilyenkor tehát a háttérben lévő alapbetegséget kell keresni. Elsősorban a következő lehetőségekre gondoljunk:

- paraneoplasiás szindróma részjelensége miatt alakul ki a folyamat: főleg pancreas- (farok), tüdő-, prosztata-, ováriumdaganatot, leukaemiát kell keresni;

- Bürger-kór (a perifériás pulzusokat mindig tapintani kell);

- fogamzásgátló tabletták szedése;

- thrombophilia;

- ritkán: autoimmun, kollagénbetegségek, köszvény $[3,5]$.

\section{Kezelés}

Az SVT kezelésének értelemszerü teendőit a 2. táblázatban foglaltuk össze.

\section{Kompresszió}

A betegek megfelelően felhelyezett rugalmas pólyát vagy kompressziós gradienst biztosító elasztikus harisnyát viseljenek. A kompresszió gyorsan csökkenti a fájdalmat, a lokális duzzanatot, gátolja a thrombus és a lokális gyulladás terjedését. Könnyebb a rugalmas pólyát, „fáslit” viselni, mint az elasztikus harisnyát, különösen az akut szakban, a menetek nyomását ugyanis változtatni lehet. Ezzel szemben az elasztikus harisnya nyomása állandó, felhúzásuk a gyulladás okozta érzékenység miatt nehéz. A pólyát egész nap kell viselni.

A felületes vénában kialakult thrombus proximalisan hosszabb lehet, mint a külsőleg tapintott elváltozás legmagasabb pontja. A thrombus tényleges kiterjedését csak ultrahangvizsgálattal lehet megállapítani [19]. Ezért a pólyát legalább $10 \mathrm{~cm}$-rel magasabbra vezessïk, mint abogy a köteg felsö határát tapintjuk [20].

A kompressziót legalább két hétig kell alkalmazni, varicositas esetén azonban a rugalmas pólya vagy elasztikus harisnya viselése hozzátartozik a krónikus kezeléshez [21].
2. táblázat |Az SVT kezelése

\begin{tabular}{l}
\hline Kompresszió: \\
\hline - rugalmas pólya; \\
- elasztikus harisnya, mindkét oldalra. \\
\hline Mobilizáció: \\
\hline - normális aktivitás, járkálás kompresszióval, nem fektetés. \\
\hline Gyógyszerek: \\
\hline - NSAID; \\
- antikoagulánsok: LMWH, UFH, fondaparinux, VKA, NOAC; \\
- helyi kezelés: gél, krém, spray; \\
- antibiotikum: kizárólag gennyes, szeptikus SVT-nél; \\
- kortikoszteroidok: csak vasculitis, autoimmun betegség esetén. \\
\hline Sebészeti kezelés: \\
\hline - crossectomia, thrombusexpresszió, endovénás thrombusaspiráció; \\
- az akut szak lezajlása után a CVI elektív kezelése hagyományos \\
mútéttel: cryomútéttel vagy endovénás ablatióval.
\end{tabular}

$\mathrm{CVI}=$ krónikus vénás elégtelenség; $\mathrm{LMWH}=$ kis molekulasúlyú heparin; NOAC $=$ új orális antikoagulánsok; NSAID = nem szteroid antiinflammatorikus gyógyszerek; SVT $=$ superficialis vénás thrombosis; $\mathrm{UFH}=$ nem frakcionált heparin; VKA = K-vitamin-antagonisták.

Egy osztrák vizsgálatban egyedüli kezelésként alkalmaztak fix kompressziós pólyát SVT kezelésére. Egy hónap múlva az ultrahangvizsgálattal igazolt SVT csak a pólya hatására a betegek $81 \%$-án lényegesen csökkent, 13\%-ban az ultrahangleletben nem volt változás, 2\%-ban a folyamat a mélyvénákra terjedt, 4\%-ban pedig új MVT alakult ki [22].

\section{Mobilizáció}

Régebben az akut fázisban a betegeket szigorúan fektették, a láb mozgatását is megtiltották. Attól féltek, hogy a thrombus leszakad és tüdőembóliát okoz. Ez a szemlélet mára alapvetően megváltozott.

Napjainkban már evidencia, hogy a fekvés a felïletes és mélyvénákban egyaránt elosegiti a thrombus terjedését, ezért kontraindikált [3, 4, 20]. A betegeket tehát rugalmas pólyával mobilizálni kell. Változatlanul folytassák napi tevékenységüket, járkáljanak. Kerüljék azonban a hosszan tartó állást, a lelógatott lábbal való ülést. Helyes, ha a vénás keringés javítására éjszakára a végtagot felpolcoljuk vagy megemeljük az ágynak a láb felőli végét.

\section{Gyógyszerek}

A klinikai gyakorlatban az SVT optimális gyógyszeres kezelését illetően nincs konszenzus. A számos variáció közül elsősorban a nem szteroid gyulladáscsökkentő gyógyszerek (NSAID) és az antikoaguláns, elsősorban kis molekulasúlyú heparin- (LMWH) kezelés között választhatunk. 
Az NSAID-ok csökkentik a fájdalmat, a perivénás gyulladást, számolni kell azonban a gastroenteralis mellékhatásokkal, vérzésekkel [20-23].

Egy vizsgálatban az NSAID-kezelés placebóval összehasonlítva a betegek 67\%-ánál csökkentette a folyamat terjedését és kiújulását, de az MVT kialakulását nem befolyásolta, továbbá a helyi panaszok és tünetek mérséklésében sem volt különbség a két csoport között. Érdekes, hogy az NSAID-dal kezelt betegeken nem volt vérzéses szövődmény [24].

$\mathrm{Az}$ antikoaguláns kezelés hatását vizsgálta egy randomizált, 562 varicosus SVT-s beteget felölelő vizsgálat. A nem frakcionált heparin (UFH), a kis molekulasúlyú heparin (LMWH) és a K-vitamin-antagonista (VKA) egyformán hatásos volt. Az antikoagulánsok egyértelmúen jobban gátolták a folyamat terjedését, mintha a beteg csak elasztikus harisnyát viselt [25].

A STENOX randomizált, kettős vak vizsgálatban 427 betegen hasonlították össze az LMWH (enoxaparin 40 mg vagy $1,5 \mathrm{mg} / \mathrm{kg}$ ), az NSAID (tenoxicam) és önmagában csak az elasztikus harisnya hatását. Tíz napot követően a profilaktikus adagban adott LMWH (enoxaparin $40 \mathrm{mg}$ ) volt a leghatásosabb kezelés [24].

A nagy adagban, naponta kétszer adott UFH-t hatásosabbnak találták, mint a profilaktikus adagban adott UFH-t. Az LMWH azonban akár profilaktikus, akár terápiás adagban, az UFH-nál még hatásosabb volt [26].

24 vizsgálat alapján szisztémásan áttekintették az SVT kezelésére vonatkozó eredményeket. A tanulmányok minősége és a metodológiai különbségek miatt egyértelmú állásfoglalást nem lehetett kialakítani. Az analízis 2469 betegre vonatkozott. A végkövetkeztetés szerint mind az NSAID, mind az LMWH szignifikánsan, mintegy 70\%kal csökkentette az SVT terjedését és kiújulását a placebóval összehasonlítva [27].

A JAMA „Clinical Evidence Synopsis” 20 ország, köztük Magyarország, 6462 betegét érintő összefoglalást készített. Az áttekintés végkövetkeztetése hasonló. Az LMWH és az NSAID gyógyszerek csökkentik az SVT terjedését és kiújulását, de a szimptómás VTE-re vonatkozó adatok ellentmondásosak [28].

Mégis mikor kezeljük LMWH-val az SVT-s betegeket? Az indikációkat a nemzetközi ajánlások alapján a 3. táblázatban közöljük.

\section{Egyéb gyógyszerek}

\section{Fondaparinux}

Egy nemrégiben végzett nemzetközi, randomizált, kettős vak, 3002 betegen végzett vizsgálat a pentaszacharid, fondaparinux (Arixtra ${ }^{\circledR}, 1 \times 2,5 \mathrm{mg} 45$ napon át) hatását placebóval hasonlította össze SVT-ben szenvedő betegeken. A primeren vizsgált hatás (halálozás, tünetekkel járó MVT és PE, ráterjedés a saphenofemoralis junctióra, SVT-kiújulás) a fondaparinuxcsoportban 0,9\%-ban, a placebocsoportban 5,9\%-ban fordult elö $(p<0,001)$. Mindkét csoportban egy-egy esetben észleltek nagyobb

\section{3. táblázat $\mid$ Az LMWH indikációja SVT kezelésére}

Hosszú szakaszú, legalább 5 cm-es köteg.

Progrediáló folyamat, kifejezett tünetek.

Combon kialakuló, junctióhoz közeli SVT.

A betegnek malignus betegsége van.

A beteg thrombophiliás.

Közelmúltban mútét vagy súlyos sérülés.

Elözetes VTE, SVT.

LMWH = kis molekulasúlyú heparin; SVT = superficialis vénás thrombosis; VTE = vénás thromboembolia

vérzést [7, 29]. A fondaparinux hatását kétségtelenül bizonyították. Széles körü alkalmazását azonban a gyógyszer meglehetősen drága ára akadályozza.

\section{Antibiotikumok}

Az antibiotikumok rutinszerú adása, ami régebben elterjedt, nemcsak felesleges, de káros is lehet. Bakteriális fertőzés csak ritkán fordul elő. Kivételt jelentenek a fóleg a felső végtagon kialakuló, intravénás kanülök, katéterek okozta gyulladásos folyamatok vagy a suppuráló SVT.

\section{Aszpirin}

A vérlemezkegátló gyógyszerek adása sem indikált SVT ellen. Ezek az artériás atherothrombosis gyógyszerei, de a vénás thromboemboliák elleni védőhatásuk nem bizonyított [5].

\section{Venotonikumok}

A venotonikumok hatása ebben az indikációban vitatott. A jelenleg folyó vizsgálatok később evidenciákat hozhatnak. Az „A” besorolású készítmények: diozmin-heszperidin kombináció (Detralex ${ }^{\circledR}$ ), kalcium-dobesilat (Doxium $^{\circledR}$, Doxilek ${ }^{\circledR}$ ), hidroxietil-rutozidok (Venoruton ${ }^{\circledR}$ ), szulodexid (Vessel due ${ }^{\circledR}$ ) a kezelés támogatói lehetnek, szerepük a szekunder prevencióban van.

Egy tanulmányban 30 SVT-s betegen az orális heparan-szulfát és az orális szulodexid hatását hasonlították össze. Két hét kezelés után mindkét gyógyszer hasonlóan csökkentette a panaszokat és tüneteket [30].

\section{$N O A C(D O A C)$}

Az új orális, direkt antikoagulánsokkal (rivaroxaban, apixaban, dabigatran) nyilvánvalóan hatásosan lehet az SVT-t kezelni. Ilyen irányú vizsgálatokat azonban eddig még nem végeztek. Kockázat-haszon profiljuk jobb, mint az UFH, LMWH, VKA gyógyszereké. Előnyük többek között, hogy az LMWH-injekciókkal szemben tabletták formájában szedhetők és ma már antidotumaik is vannak. Nem ismerjük azonban az SVT gyógyítására ajánlott dózist, a kezelés időtartamát, és ezek meglehetősen drága gyógyszerek [31, 32]. 


\section{Helyileg ható szerek}

Helyileg heparin-, hirudin-, pentozán-poliszulfát, troxerutintartalmú krémek, kenőcsök, gyulladáscsökkentó diklofenak-, piroxicam-, ketoprofengélek és borogatás alkalmazható [33]. A sérülékeny bőrön át azonban könynyen jön létre kontakt szenzibilizáció. A legtöbb bajt a fenilbutazon, a perubalzsam és a paraállású vegyületek okozzák.

Egyesek az SVT-t a gyulladt véna fölé adott heparinquadlikkal kezelik [34]. A lob ilyenkor észrevehetően csökken, de az eljárás fájdalmas és az intracutan adott heparin bőrnekrózist okozhat.

\section{Sebészi kezelés}

A Német Sebész Társaság ajánlása szerint, varicosus SVT esetén, ha a thrombus kis kaliberú oldalágban vagy nagy kaliberú, de a junctiótól távol levő törzsvénában helyezkedik el, esetenként célszerú kis stichincisióból a thrombust exprimálni. Ez a feszítő fájdalmat azonnal enyhíti, akár meg is szünteti [35]. A szegmentált, letokolt vérrögök eltávolítására több incisio szükséges. A lokális anaesthesia önmagában is fájdalmas. Célszerü ezért nem a florid, legérzékenyebb stádiumban, kis nyomással végezni az expressziót [36].

$\mathrm{Az}$ ambuláns thrombectomia során helyi érzéstelenítésben, 11-es szike hegyével, a bőrön áthatolva, kis incisiót ejtünk a thrombotizált vénán és a thrombust felfelé és lefelé exprimáljuk. A thrombust csak a folyamat kezdetén lehet eltávolítani, amíg a vérrög nem rögzült. Sutura nem szükséges. A beteg egy hónapig rugalmas pólyát viseljen. Residualis pigmentáció, ami SVT után gyakran megfigyelhető, sokkal ritkábban alakul ki, ha a thrombust exprimáljuk $[3,4]$.

Ha az ascendáló folyamat a vena saphena magna vagy vena saphena parva beömlését megközelíti, crossectomiát kell végezni. A crossectomia a francia és német phlebológiai gyakorlatban használt kifejezés, az angol-amerikai „high ligation” megfelelője, a törzsvéna magas lekötését jelenti, a lágyékhajlatban, közvetlenül a junctiónál, valamennyi oldalág megszakításával együtt. Az American Venous Forum akkor tanácsolja a magas lekötést, ha az SVT a junctiótól $\mathrm{l} \mathrm{cm}$-re van (2B szintû ajánlás) [37]. Az európai, így a magyar gyakorlat sokkal óvatosabb: a crossectomiát már akkor elvégezzük, ha a terjedő folyamat a combon a lágyékhajlatot egytenyérnyire megközelíti.

A beavatkozás ilyenkor különösen gondos műtéti technikát igényel. A junctiót óvatosan kell kipreparálni, nehogy a sebész maga préselje a thrombust a véráramba. Ha a vena saphena magna a beömlés előtt is kitöltött, először distalisan kell a vénát lekötni. Ezt követően kell a vénán kis metszést ejteni és pozitív, túlnyomásos lélegeztetés mellett, „visszavéreztetve” a thrombust a vénából kihúzni. Csak ezután szabad a ligaturát proximalisan is felhelyezni. A crossectomiát LMWH-védelemben végez- zük, profilaktikus adagban adjuk a gyógyszert, 10 napon át [3].

A crossectomia, sajnos, nem jelent abszolút védelmet, mert az SVT a combon és lábháton lévő perforáns vénákon keresztül is ráterjedhet a mélyvénákra.

Varicosus SVT esetén felmerül az akut varicectomia lehetősége. A sebészeti taktika azonban ilyenkor általában mértéktartó, óvatos. Ez kétlépéses mútétet jelent. Az elsô mútét - a sebgennyedéstől és a VTE-s szövődményektốl való félelem miatt - csak crossectomia. Mintegy fél évvel később, amikor a konzervatív kezelés hatására az akut tünetek megszúntek és a vénák már rekanalizálódtak, egy második mútéttel távolítják el a kóros visszereket [38].

Ezzel szemben Nagy Imre nemrégiben megjelent tanulmányában ilyenkor is radikális mútétet javasol. A crossectomiát szükség szerint felületes vagy mélyvénás

4. táblázat $\mid$ Kezelési irányelvek az Egyesült Államokban és Németországban $[33]$

\begin{tabular}{|c|c|}
\hline Amerikai Egyesült Államok & Németország \\
\hline Spontán SVT & Spontán SVT \\
\hline a) rövid szegment & kis kaliberü mellékág \\
\hline \multicolumn{2}{|l|}{ junctiótól távol } \\
\hline Diclofenac vagy más NSAID & NSAID vagy \\
\hline $\begin{array}{l}\text { helyileg diclofenacgél, } \\
\text { heparingél }\end{array}$ & $\begin{array}{l}\text { stich incisio, } \\
\text { thrombusexpresszió }\end{array}$ \\
\hline $\begin{array}{l}\text { a tünetek megszűntéig, } \\
\text { maximum négy hétig }\end{array}$ & hûtés, kompresszió \\
\hline b) hosszú szegment & Varicosus SVT \\
\hline junctióhoz közel & junctióhoz közel \\
\hline $\begin{array}{l}\text { profilaktikus vagy intermedier } \\
\text { dózisú }\end{array}$ & $\begin{array}{l}\text { profilaktikus vagy terápiás } \\
\text { dózisú }\end{array}$ \\
\hline $\begin{array}{l}\text { UFH/VKA (INR: 2-3) vagy } \\
\text { LMWH }\end{array}$ & heparinizálás, \\
\hline \multirow[t]{3}{*}{ maximum négy hétig } & minimum négy hétig, vagy \\
\hline & $\begin{array}{l}\text { crossectonmia és LMWH négy } \\
\text { hétig, }\end{array}$ \\
\hline & $\begin{array}{l}\text { kompresszió minimum négy } \\
\text { hétig }\end{array}$ \\
\hline
\end{tabular}

nincs ajánlás az NSAID

és LMWH kombinációjára,

a gyógyszeres kezelés

előnyösebb, mint a sebészi

Varicosus $S V T$
junctiótól távol
nagy kaliberú mellékág
NSAID, hútés, kompresszió
vagy
stich incisio,
thrombusexpresszió

LMWH = kis molekulasúlyú heparin; NSAID = nem szteroid antiinflammatorikus gyógyszerek; SVT = superficialis vénás thrombosis; $\mathrm{UFH}=$ nem frakcionált heparin; VKA = K-vitamin-antagonista. 
thrombectomiával kombinálja, majd a varicosus ereket, a kitöltő thrombussal együtt, stripperrel vagy szakaszonként végzett metszésekból távolítja el. A posztoperatív szakban a betegeket terápiás dózisban adott antikoagulánsokkal kezelték. A mútét után 188 operált betegnél a heves panaszok azonnal megszüntek, sebgennyedés két esetben, MVT egy esetben fordult elő, PE-t nem észleltek [39]. Radikális mútétet mások is javasolnak, a beavatkozás kétségtelenül költséghatékony, a beteg hamar hazabocsátható $[40,41]$. Újabban a varicosus SVT-t cryomútéttel [42] vagy endovénás ablatióval [43] is kezelik.

\section{Mütét vagy antikoaguláns kezelés?}

Zaraca az SVT két formáját különbözteti meg, ezek kezelése is különböző. l-es típusban a thrombus nem éri el a saphenofemoralis billentyüt. Ilyenkor egyszerüen crossectomiát kell végezni. A 2-es típusban a thrombus a saphenofemoralis billentyưn túlra terjed. Ebben az esetben crossectomia, thrombectomia és antikoaguláns kezelés szükséges [44].

Sullivan hat olyan vizsgálat eredményeit összegezte, amelyekben a crossectomia és az antikoaguláns kezelés eredményeit hasonlították össze. Az SVT tovaterjedése egyformán ritkán fordult elő, de szövődményeket és VTE-t a sebészeti kezelés során gyakrabban észleltek [45].

Egy másik vizsgálat egyformán hatásosnak találta, ha a combon lévő thrombophlebitist a saphenofemoralis junctio lekötésével vagy négy héten át enoxaparinnal kezelték [46].

Az American Venous Forum a saphenofemoralis junctiót megközelítő SVT esetén az antikoaguláns kezelést a magas lekötés elfogadható terápiás alternatívájának tekinti (2B szintű ajánlás) [37].

Az Egyesült Államokban és Németországban ajánlott kezelési irányelveket a 4. táblázatban közöljük [33].

\section{Felületes vénás thrombosis a felső végtagon}

A folyamat ilyenkor ép vénán alakul ki. Elsősorban tartós kanülálás következtében jön létre, de intravénás injekció, paravénásan adott injekció, a véna falát irritáló tömény oldat, trauma, rovarcsípés is okozhatja. Egy francia kórházban a karvénán tartósan kanülált betegek 9,9\%-ánál lépett fel SVT, az esetek 1,1\%-a pedig suppurált [47]. Aminosavak, intravénás lipidoldatok, hypertoniás glükózoldatok, kemoterápiás kezelés ismerten thrombogen hatásúak.

Égő fájdalom, bőrvörösség már az injekció beadása alatt jelentkezik, majd érzékeny köteg, beszűrődés alakul ki, nemegyszer láz kíséretében, különösen ismételt injekciók után.

Ha az SVT-t kanül tartja fenn, a katétert, beduzzadó kanült azonnal el kell távolítani és bakteriológiai tenyésztésre kell küldeni. Lázas, szeptikus állapotban a tenyésztés eredményének megfelelő, célzott antibiotikus kezelés szükséges. Különben NSAID-készítmények adhatók. Helyileg gyulladáscsökkentő, fájdalomcsillapító kenőcsök, jegelés, borogatás alkalmazható. A kart felpolcoljuk, nyugalomba helyezzük.

A kiváltó ok megszüntetésével a gyulladás is hamar megszűnik, postphlebitises köteget azonban néha hónapokon át lehet tapintani.

Sebészeti beavatkozásra (beolvadás esetén: feltárás, szövetelhalásnál: necrectomia) szerencsére ritkán kerül sor.

A kórházi SVT kialakulása megelőzhető gondos, szövetkímélő vénapunkcióval, az endothelkárosító injekciók kerülésével, az irritáló oldat beadása után a véna átöblítésével, az infúziós idő csökkentésével.

A vena axillaris már mélyvénának számít. Az axillaris thrombosis profilaxisa LMWH-val csak halmozott rizikófaktorok egyidejü fennállása esetén indokolt [3-5].

\section{Suppurativ SVT}

Gennyes SVT napjainkban szerencsére ritkán fordul elő. Drogfüggő fiatalokon, súlyos, égett betegeken találkozhatunk a kórképpel. Veszélye, hogy bacteriaemiát, szepszist, endocarditist okozhat. A célzott antibiotikus kezelés mellett ilyenkor sürgős sebészi feltárás, drenálás szükséges. A suppuráló vénát excindálni kell. A sebet nyitva kell kezelni, később szekunder varrat vagy bőrátültetés lehetséges.

\section{SVT ritka kórképekben}

\section{Mondor-betegség}

Ez az anterolateralis mellkasfal subcutan vénáinak szklerotizáló thrombophlebitise $[3,4,48]$. Henri Mondor írta le 1939-ben.

A thrombosis és gyulladás a vena thoracoepigastrica, a vena thoracica lateralis és a vena epigastrica superior közül általában egy vénát érint, de előfordul, hogy mindhárom vénára kiterjed. A folyamat soha nem érinti az emlő belső kvadránsait.

A Mondor-betegség nókön háromszor gyakrabban alakul ki, mint férfiakon. Minden életkorban előfordul, de leggyakoribb a 30-60 éves korcsoportban.

A kórkép létrejöttében a vénát ért közvetlen trauma, a nyomás miatt stagnáló vér játszhat szerepet. Egyesek szerint az emlő ismétlődő mozgása, az összehúzódó és ellazuló pectoralis izmok mentén vezet a vénák megnyúlásához és relaxációjához.

Mások szerint a szoros melltartó, füző vagy a hónalj rendszeres borotválása okozza a betegséget [49]. A betegek egynegyede a betegség közvetlen kialakulása előtt radikális emlőmútéten - általában azonos oldali mastectomián és axillaris dissectión - esett át. Újabban az emlő szilikonimplantációját követően gyakrabban megfigyelték. Emlőplasztikai mütétek után 1\%-ban fordul elő [50]. 
A klinikai képre jellemző a hirtelen kezdet, a lineáris, thrombotizált vénás köteg megjelenése a mellkas oldalsó felszínén. A köteg a submammalis redőn és a bordaíven túl a hasfalra is ráterjedhet vagy érinti az emlő külső kvadránsait.

Kezdetben a véna vöröses és érzékeny, majd fájdalmatlan, tömött, fibrosus köteggé alakul, mint „pasfonál” („en fil de fer”) húzódik a mellkasfalon és a hasfal felső részén („steel wire phlebitis”). A köteg különösen szembetûnő, ha az emlőt megemeljük vagy a kart abdukáljuk. Általános tünetek nincsenek. A kórképet kitágult tejvezetéktől, bőrmetasztázisoktól kell elkülöníteni.

A kezelés tüneti. NSAID-készítmények, fájdalomcsillapítók adhatók, helyileg pedig gyulladáscsökkentő kenőcsöket, borogatást lehet alkalmazni. Antibiotikumok, kortikoszteroidok, antikoagulánsok adása felesleges és káros.

A betegség jóindulatú, spontán gyógyul, nem migráló jellegű, nem újul ki. A köteg három hét alatt általában eltünik, csak ritkán fordul elő, hogy hat hónapon át tapintható.

A Mondor-betegség jelentősége, hogy 3-10\%-ban emlöcarcinoma csatlakozhat hozzá. Ezenkívül a kórkép, mint paraneoplasiás jel, a szervezetben megbújó okkult carcinomára utalhat. Ezért ezeket a betegeket meg kell figyelni. Az emlőket rendszeresen meg kell vizsgálni és mammográfiát, ultrahangvizsgálatot, tumormarkermeghatározást kell végezni [3-5].

\section{A penis superficialis vénás thrombosisa}

A vena dorsalis penisen hirtelen lép fel, csaknem fájdalmatlan köteg. Patogenezise ismeretlen. Trauma, ismételt sérülés okozhatja. A penis Mondor-betegségének tartják [51]. Hasonló kórkép a várandós nőkön ritkán kialakuló vulvavarixok SVT-je.

\section{Bürger-Winiwarter-kór}

Thrombangitis obliterans. Elsősorban a kis artériák mediumát érintő, gyulladásos, okkluzív betegség. A betegség egyik diagnosztikus kritériuma az SVT, ami föleg mint thrombophlebitis migrans vagy saltans jelentkezik [52]. Egy 22 Bürger-kóros betegre vonatkozó vizsgálat során nyolc betegen (36,4\%-ban) észleltek SVT-t [53].

\section{Behçet-szindróma}

Krónikus, recidiváló, rohamokban lezajló, szeptikus, allergiás betegség: iridocyclitis, hypopyon, száj- és nemiszerv-afták, SVT, arthritis, epididymitis, nyál- és könnymirigyduzzanat, meningealis tünetek jellemzik. 2319 Behçet-szindrómás beteg 53,3\%-án alakult ki SVT és 29,8\%-án MVT [54]. Spontán SVT és erythema nodosumszerü laesiók gyakran előjelei a betegség súlyos, visceralis szövődményeinek [52].

\section{Hughes-Stovin-szindróma}

SVT, arteria pulmonalis aneurysma, gynecomastia $[3,5]$.

\section{Koblmeier-Degos-szindróma}

SVT, arteritis, malignus atrophiás papulosis $[3,5]$.

\section{Horton óriássejtes arteritis (Horton-Magath-Brown-betegség)}

Arteritis temporalis granulomatosa. Fél oldalon, az arteria temporalison fellépő óriássejtes, granulomatosus arteritis, 50 év körül alakul ki, SVT kísérheti $[3,5]$.

\section{Takayasu-arteritis (Takayasu-Onishi-szindróma)}

Az aortaívből származó nagyerek granulomatosus, obliteratív gyulladása. SVT csatlakozhat a tünetekhez $[3,5]$.

\section{Ajánlások *}

1. Minden spontán SVT-ben vagy kiújult varicosus SVT-ben szenvedő betegen keresni kell a rizikófaktorokat, különösen daganatos betegséget, thrombophiliát.

2. A klinikai vizsgálat nem tájékoztat az SVT valóságos kiterjedéséről, sem a mélyvénák állapotáról. Ezért kötelező a betegek alapos color duplex ultrahangvizsgálata.

3. A duplex ultrahangvizsgálatot az érintett és az ellenkező oldalon is el kell végezni.

4. Terjedő folyamatnál, különösen, ha az SVT a junctiót $5 \mathrm{~cm}$-re megközelíti, az ultrahangvizsgálatot gyakran meg kell ismételni. Akkor is indikált ez a vizsgálat, ha a megfelelő kezelés ellenére a klinikai állapot romlik.

5. Minden SVT-s betegen kompressziós kezelést kell alkalmazni.

6. Azonnali mobilizáció szükséges, elasztikus kompresszióval. Nem szabad a beteget ágyba fektetni.

7. Duplex ultrahangvizsgálattal bizonyítottan $5 \mathrm{~cm}$-rel hosszabb vénás szakaszra terjedő SVT esetén, a beteget LMWH-val kell kezelni, intermedier vagy terápiás dózisban, négy héten át. Az antikoaguláns kezelés adagja és időtartama a kísérő betegségektől vagy a VTE más rizikófaktoraitól függ.

8. Terjedő, $10 \mathrm{~cm}$-nél hosszabb SVT-s betegeken, ha más VTE-rizikófaktoruk is van, subcutan fondaparinuxkezelés profilaktikus adagban megfontolandó.

9. Junctio közeli folyamatnál a terápiás dózisú LMWH vagy sebészeti kezelés (magas lekötés) egyaránt elfogadható eljárás. 
10. Térd alatti varicosus SVT esetén a helyileg alkalmazott NSAID, heparin, heparinoid krém és elasztikus harisnya elfogadható kezelés.

*International Consensus Statement of European Venous Forum, North American Thrombosis Forum, International Union of Angiology, Union Internationale du Phlebologie, Cardiovascular Disease Educational and Research Trust and Central European Vascular Forum $2013[5,6]$.

Anyagi támogatás: A közlemény megírása anyagi támogatásban nem részesült.

A szerző a cikk végleges változatát elolvasta és jóváhagyta.

Érdekeltségek: A szerzőnek nincsenek érdekeltségei.

\section{Irodalom}

[1] Decousus, H., Quéré, I., Presles, E., et al.: Superficial venous thrombosis and venous thromboembolism: a large prospective epidemiologic study. Ann. Intern. Med., 2010, 152(4), 218-224.

[2] Frappé, P., Bertoletti, L., Presles, E., et al.: Seasonal variation in the superficial vein thrombosis frequency. Thromb. Res., 2015, 136(6), 1116-1119.

[3] Sándor, T.: Treatment of superficial thrombophlebitis. [A felületes thrombophlebitis kezelése.] Orv. Hetil., 2005, 146(2), 81-84. [Hungarian]

[4] Sándor, T.: Treatment of superficial thrombophlebitis. [A felületes thrombophlebitis kezelése.] Orv. Hetil., 2009, 150(51), 2319-2322. [Hungarian]

[5] Kalodiki, E., Stvrtinova, V., Allegra, C.: Superficial vein thrombosis: a consensus statement. Int. Angiol., 2012, 31(3), 203216.

[6] Nicolaides, A. N., Fareed, J., Kakkar, A. K., et al.: Prevention and treatment of venous thromboembolism - International consensus statement. Guidelines according to scientific evidence. Int. Angiol., 2013, 32(2), 111-260.

[7] Decousus, H., Prandoni, P., Mismetti, P., et al. (The CALISTO Study Group: Fondaparinux for the treatment of superficial-vein thrombosis in the legs. N. Engl. J. Med., 2010, 363(13), 12221232 .

[8] Binder, B., Lackner, H. K., Salmbofer, W., et al.: Association between superficial vein thrombosis and deep vein thrombosis of the lower extremities. Arch. Dermatol., 2009, 145(7), 753-757.

[9] Wichers, I. M., Di Nisio, M., Buller, H. R., et al.: Treatment of superficial vein thrombosis to prevent deep vein thrombosis and pulmonary embolism: a systematic review. Haematologica, 2005, 90(5), 672-677.

[10] Cannegieter, S. C., Horváth-Puhó, E., Schmidt, M.: Risk of venous and arterial thrombotic events in patients diagnosed with superficial vein thrombosis: a nationwide cohort study. Blood, 2015, 125(2), 229-235.

[11] Partsch, H., Mostbeck, A.: Lungenembolien bei oberflächlicher Thrombophlebitis? Acta Med. Austr., 1979, 6, 159-160.

[12] Verlato, F., Zucchetta, P., Prandoni, P., et al.: An unexpectedly high rate of pulmonary embolism in patients with superficial thrombophlebitis of the thigh. J. Vasc. Surg., 1999, 30(6), $1113-1115$

[13] Crişan, S., Vornicescu, D., Crişan, D., et al.: Concomitant acute deep venous thrombosis and superficial thrombophlebitis of the lower limbs. Med. Ultrason., 2011, 13(1), 26-32.
[14] Sándor, T., Fáy, K., Hunyi, L.: The diagnosis of deep venous thrombosis with the help of duplex scanning. [A mélyvénás thrombosis diagnosztikája duplex scanning segítségével.] Magy. Seb., 1992, 45, 31-38. [Hungarian]

[15] Rabe, E., Pannier-Fischer, F., Bromen, K., et al.: Epidemiological study to investigate the prevalence and severity of chronic venous disorders in the urban and rural residential populations. Phlebologie, 2003, 32(1), 1-14.

[16] Blattler, W., Schwarzenbach, B., Largiader, J.: Superficial vein thrombophlebitis - a serious concern or much ado about little? VASA, 2008, 37(1), 31-38.

[17] Malone, P. C., Agutter, P. S.: To what extent might deep venous thrombosis and chronic venous insufficiency share a common etiology? Int. Angiol., 2009, 28(4), 254-268.

[18] Van Den Bos, R. R., Neumann, M., De Roos, K. P., et al.: Endovenous laser ablation-induced complications: review of the literature and new cases. Dermatol. Surg., 2009, 35(8), 1206-1214.

[19] Marković, M., Maksimovilntć, Z., Maksimović, I., et al.: The role of duplex sonography in surgical treatment of acute progressive thrombophlebitis of great saphenous vein. Int. Angiol., 2011, $30(5), 434-440$.

[20] Partsch, H., Rabe, E., Stemmer, R.: Superficial thrombosis. In: Compression therapy of the extremities. Phlebologiques Françaises, Paris, 2000, Vol. Chapter 10.1.4.2, 300-304.

[21] Clement, D. L.: Superficial vein thrombosis: more dangeous, than anticipated. Phlebology, 2013, 20(4), 188-192.

[22] Mayer, W., Partsch, H.: Superficial phlebitis: A harmless disorder? Scope Phlebol., 1999, 6(36), e8.

[23] Ferrari, E., Pratesi, C., Scaricabarozzi, et al.: Clinical study of the therapeutic efficacy and tolerance of nimesulide in comparison with a sodium diclofenac in the treatment of acute superficial thrombophlebitis. Minerva Cardioangiol., 1992, 40(11), 455460.

[24] The Superficial Thrombophlebitis Treated by Enoxaparin Study Group: A pilot randomized double-blind comparison of a lowmolecular weight heparin, a nonsteroidal anti-inflammatory agent and placebo in the treatment of superficial vein thrombosis. Arch. Intern. Med., 2003, 163(14), 1657-1663.

[25] Belcaro, G., Nicolaides, A. N., Errichi, B. M., et al.: Superficial thrombophlebitis of the legs, a randomized, controlled, followup study. Angiology, 1999, 50(7), 523-529.

[26] Marchiori, A., Verlato, E., Sabbion, P., et al.: High versus low doses of unfractionated heparin for the treatment of superficial thrombophlebitis of the leg. A prospective, controlled, randomized study. Haematologica, 2002, 87, 523-527.

[27] Di Nisio, M., Wichers, I. M., Middeldorp, S.: Treatment for superficial thrombophlebitis of the leg. Cochrane Database Syst. Rev., 2007, (4), CD004982.

[28] Di Nisio, M., Middeldorp, S.: Treatment of lower extremity superficial thrombophlebitis. JAMA, 2014, 311(7), 729-730.

[29] Decousos, H., Bertoletti, L., Frappé, P.: Spontaneous acute superficial vein thrombosis of the legs: do we really need to treat? J. Thromb. Haemost., 2015, 13(Suppl. 1), S230-S237.

[30] Messa, G., La Placa, G., Puccetti, L., et al: Effectiveness and tolerability of heparan sulfate in the treatment of superficial thrombophlebitis. Controlled clinical study vs sulodexide. Minerva Cardioangiol., 1997, 45(4), 147-153.

[31] Paramanathan, V.: Rivaroxaban: future in anticoagulation practice? Hematology, 2008, 13(5), 257-260.

[32] Combe, S., Buller, H. R.: New treatments for venous thromboembolic disease. J. Mal. Vasc., 2011, 36(Suppl. 1), S16-S19.

[33] Giannoukas, A. D.: Current management of superficial thrombophlebitis of the lower limb. Phlebolymphology, 2013, 20(3), $127-132$

[34] Marton, T., Sándor, T., Izinger, E.: Treatment of thrombophlebitis with intracutaneous heparin injection. [A thrombophlebitis kezelése intracutan heparin injekcióval.] Orv. Hetil., 1965, 106(32), 1505-1507. [Hungarian] 
[35] Reich-Supke, S., Stücker, M.: Therapie der tiefen Venenthrombose und Thrombophlebitis. Vasomed, 2010, 5, 234-239.

[36] Bihari, I.: The treatment of superficial phlebitis. In: Bihari, I.: Varicosity and its treatment. [A felületes phlebitis kezelése. In: Bihari, I.: Visszérbetegség és kezelése.] Á+B Kiadó, Budapest, 2004. 125-131. [Hungarian]

[37] Hingorani, A., Ascher, E.: Superficial venous thrombophlebitis. In: Gloviczki, P. (ed.): Handbook of venous disorders. Hodder Arnold, Part of Hachette, London, 2009, 314-319.

[38] Denzel, C., Lang, W.: The diagnosis and therapy of progressive thrombophlebitis of epifascial leg veins. [Die Diagnostik und Therapie der progressiven Thrombophlebitis epifaszialer Beinvenen.] Zentralbl. Chir., 2001, 126(5), 374-378. [German]

[39] Nagy, I.: The traditional surgical treatment of ascending varicophlebitis. [Az ascendáló varicophlebitis hagyományos mútéti kezelése.] Érbetegségek, 2015, 22(3), 101-107. [Hungarian]

[40] Hetényi, A.: Radical varicectomy in ascending LSV varicophlebitis. Phlebology, 1995, 95(Suppl. 1), 454-457.

[41] Horváth, T., Czenkár, B.: Experience with surgical treatment of superficial thrombophlebitis (varicophlebitis). [Tapasztalataink a superficialis thrombophlebitis (varicophlebitis) sebészi kezelésével.] Orv. Hetil., 1990, 131(8), 391-393. [Hungarian]

[42] Vizsi, L., Bálint, I. B., Farics, Á., et al.: Treatment of varicophlebitis with cryo-surgery. [Varicophlebitis kezelése cryo-mútéttel.] Érbetegségek, 2014, 21(2), 73-75. [Hungarian]

[43] Enzler, M. A., Russel, D., Schimmelpfennig, J.: Thermal ablation in the management of superficial thrombophlebitis. Eur. J. Vasc. Endovasc. Surg., 2012, 43(6), 726-728.

[44] Zaraca, F., Ebner, H.: Ascending thrombophlebitis of the greater saphenous vein: proposal of a new morphological classification. Chir. Ital., 2008, 60(3), 419-424.

[45] Sullivan, V., Denk, P. M., Sonnard, S. S., et al.: Ligation versus anticoagulation: treatment of above-knee thrombophlebitis not involving the deep venous system. J. Am. Coll. Surg., 2001, 193(5), 556-562.
[46] Lozano, F. S., Almazan, A.: Low-molecular-weight heparin versus sapheno-femoral disconnection for the treatment of aboveknee greater saphenous thrombophlebitis: a prospective study. Vasc. Endovascular. Surg., 2003, 37(6), 415-420.

[47] Richet, H., Hubert, B., Nitemberg, G., et al.: Prospective multicentre study of vascular-catheter-related complications and risk factors for positive central-catheter cultures in intensive care unit patients. J. Clin. Microbiol., 1990, 28(11), 2520-2525.

[48] Álvarez Garrido, H., Garrido-Rios, A. A., Sanz-Muñoz, C., et al.: Mondor's disease. Clin. Exp. Dermatol., 2009, 34(7), 753-756.

[49] Vincenza Polito, M., De Cicco, P., Apicella, R.: Tight bra in a 34-year-old woman. An unusual case of Mondor's disease. Ann. Vasc. Dis., 2014, 7(2), 149-151.

[50] Pignatti, M., Loschi, P., Pedrazzi, P., et al.: Mondor's disease after implant-based breast reconstruction. Report of three cases and review of the literature. J. Plast. Reconstr. Aesthet. Surg., 2014, 67(11), e275-e277.

[51] Al-Mwalad, M., Loertzer, H., Wicht, A., et al.: Subcutaneous penile vein thrombosis (Penile Mondor's Disease) pathogenesis, diagnosis and therapy. Urology, 2006, 67(3), 586-588.

[52] Coskun, B., Öztürk, P., Saral, Y.: Are erythema nodosum-like lesions and superficial thrombophlebitis prodromal in terms of visceral involvment in Behçet's disease? Int. J. Clin. Pract., 2005, 59(1), 69-71

[53] Stvrtinova, V., Ambrozy, E., Stvrtina, S., et al.: 90 years of Bürger's disease - what has changed? Bratisl. Lek. Listy, 1999, 100(3), 123-128.

[54] Sarica-Kucukoglu, R., Aktag-Kose, A., Kayabali, M., et al.: Vascular involvment in Behçet's disease: a retrospectve analysis of 2319 cases. Int. J. Dermatol., 2006, 45(8), 919-921.

(Sándor Tamás dr., Budapest, Kútvölgyi út 4., 1125 e-mail: dr.sandor.tamas@t-online.hu)

\section{Pályázati felhívás}

Professzor Dr. Fehér János munkássága, szakmai és erkölcsi hagyatéka páratlan és maradandó az orvostudományban. Ezért a Semmelweis Egyetem Általános Orvostudományi Kar II. sz. Belgyógyászati Klinika volt igazgatója, „A hepatológiai szabad gyökös és immunológiai vonatkozásai" című program vezetöjének, az Orvosi Hetilap föszerkesztöjének emlékére Alapitvány létesült. Az alapítványt a Fővárosi Bíróság 2011. március 7-én 11.335. sorszám alatt nyilvántartásba vette.

Dr. Fehér János Emlékére Alapítvány fő célja: a belgyógyászat, különösen a hepatológia szabad gyökös és immunológiai vonatkozásai témakörök kutatásának fejlesztése, támogatása, illetve ösztönzése oly módon, hogy a fiatal egyetemi oktatók és hallgatók az alapítvány kamatából részesüljenek. Az alapítvány célja olyan orvosok, PhD-hallgatók dijazása, akik kiemelkedő tudományos munkát végeznek és eredményeiket az Orvosi Hetilapban publikálják.

A dolgozatot „Dr. Fehér János pályázat” megjelölésével kell benyújtani.

A pályázatot 2017. április 5-ig lehet beküldeni a Kuratórium elnökének (Dr. Rácz Károly) vagy titkárának (Dr. Lengyel Gabriella) - Semmelweis Egyetem, II. sz. Belgyógyászati Klinika, 1088 Budapest, Szentkirályi u. 46. címre.

A pályázathoz mellékelni kell a pályázó önéletrajzát és a dolgozatot.

A dijak odaítéléséről a kuratórium dönt. A dij átadására a Markusovszky ünnepségen kerül sor.

$A z$ ünnepségen a nyertes pályázó maximum 5-10 perces elöadásban foglalja össze az eredményeit. 